\title{
MINERAL INFORMATION AT MICRON TO KILOMETER SCALES: LABORATORY, FIELD, AND REMOTE SENSING IMAGING SPECTROMETER DATA FROM THE ORANGE HILL PORPHYRY COPPER DEPOSIT, ALASKA, USA
}

\author{
Raymond F. Kokaly ${ }^{1}$, Todd M. Hoefen ${ }^{1}$, Garth E. Graham ${ }^{1}$, Karen D. Kelley ${ }^{1}$, Michaela R. Johnson ${ }^{1}$, \\ Bernard E. Hubbard ${ }^{2}$, Richard J. Goldfarb ${ }^{3}$, Marcel Buchhorn ${ }^{4}$, and Anupma Prakash ${ }^{4}$ \\ ${ }^{1}$ U.S. Geological Survey, Denver, Colorado, USA \\ ${ }^{2}$ U.S. Geological Survey, Reston, Virginia, USA \\ ${ }^{3}$ School of Earth Sciences and Resources, China University of Geosciences, Beijing, China \\ ${ }^{4}$ University of Alaska Fairbanks, Fairbanks, Alaska, USA
}

\begin{abstract}
Using imaging spectrometers at multiple scales, the USGS, in collaboration with the University of Alaska, is examining the application of hyperspectral data for identifying largetonnage, base metal-rich deposits in Alaska. Recent studies have shown this technology can be applied to regional mineral mapping [1] and can be valuable for more local mineral exploration [2]. Passive optical remote sensing of high latitude regions faces many challenges, which include a short acquisition season and poor illumination due to low solar elevation [3]. Additional complications are encountered in the identification of surface minerals useful for mineral resource characterization because minerals of interest commonly are exposed on steep terrain, further challenging reflectance retrieval and detection of mineral signatures. Laboratory-based imaging spectrometer measurements of hand samples and field-based imaging spectrometer scans of outcrop are being analyzed to support and improve interpretations of remote sensing data collected by airborne imaging spectrometers and satellite multispectral sensors.
\end{abstract}

Index Terms - hyperspectral, imaging spectroscopy, geology, mineral exploration, PRISM, MICA

\section{DATA COLLECTION AND PROCESSING}

\subsection{Acquisition of imaging spectrometer data, field sampling, and spectral measurements}

In July, 2014, data were collected using the HyMap2 ${ }^{*}$ sensor [4] over the Nabesna Area of Interest (AOI) in the eastern Alaska Range. The HyMap2 imaging spectrometer measured reflected sunlight in 126 narrow channels spanning the 0.4 to 2.5 micron wavelength region of the electromagnetic spectrum. The data were collected at a nominal $6 \mathrm{~m}$ groundinstantaneous field of view (GIFOV). Simultaneously with the airborne survey, representative samples of geologic units were collected for ground verification of remote sensing data. In the Nabesna AOI, sampling focused on altered and unaltered parts of intrusions hosting mid-Cretaceous porphyry copper deposits and occurrences at Orange Hill, Bond Creek, Baultoff, and Horsfeld. In July, 2015, fieldbased imaging spectrometer data were collected using the Hyspex imaging spectrometer [5-6] (HyLab, University of Alaska Fairbanks) across the Orange Hill copper deposit (with approximately $30 \mathrm{~cm}$ pixel size and $6.5 \mathrm{~nm}$ bandpass in the shortwave infrared region, 1.0 to 2.5 microns). Furthermore, additional rock samples were collected across the deposit. For selected mineralized hand samples, a laboratory imaging spectrometer system (Corescan Pty Ltd, Australia) was used to collect imaging spectrometer data, with 500 micron pixel size. During both field seasons, spectra of ground calibration sites and exposed rocks and soils were collected using an ASD FieldSpec4 spectrometer (Panalytical, Boulder, Colorado, USA).

\subsection{Spectral processing}

The HyMap2 data were converted from radiance to reflectance using a multistep calibration process [1]. First, the radiance data were converted to apparent surface reflectance using the radiative transfer correction program ATCOR-4 (ReSe Applications, Zurich, Switzerland) and ground-based reflectance measurements from a calibration site. Field-based spectral measurements of areas of light and dark materials were used to correct Hyspex imaging spectrometer data to reflectance using the empirical line correction method. The empirical line method was also used to cross-calibrate ASTER multispectral data using the HyMap2 reflectance signatures in selected areas of overlap. Laboratory imaging spectrometer data were collected by Corescan and provided in reflectance. 
Reflectance data from all spectrometers were processed using the Material Identification and Characterization Algorithm (MICA), a program written in Interactive Data Language (IDL; ExelisVIS, Boulder, Colorado, USA). MICA is a module of the USGS PRISM (Processing Routines in IDL for Spectroscopic Measurements) software [7]. The MICA analysis identifies the dominant mineral or mineral assemblage, with characteristic absorption features in the scanned wavelength range, in each pixel of imaging spectrometer data by comparing its reflectance spectrum to a reference spectral library of minerals, vegetation, water, and other materials.

\section{RESULTS}

Altered rock associated with porphyry $\mathrm{Cu}-\mathrm{Mo}-\mathrm{Au}$ mineralization at Orange Hill is dominated by kilometerscale zones of predominantly muscovite (sericite/white mica) that was mapped with HyMap2 data, although conspicuous zones of clay (montmorillonite) are also mapped throughout the area (figure 1). Finer scale mapping of surface minerals derived from Hyspex scans shows the detection of a similar suite of minerals, including gypsum and chlorite (figure 2). These results are consistent with existing geologic information determined during past regional mapping [8-11]. Preliminary analysis of the Corescan imagery shows the same hydrothermal minerals distributed within single specimens and across the entire region of altered rock (figure 3).

The results indicate that consistent mineral information can be derived across multiple scales, from micron level measurements in the laboratory to kilometer level coverage with remote sensing. There are shifts in the representation of the spectrally dominant minerals across the measurement levels; for example, the less consistent detection of muscovite at the field level and less common detection of gypsum at the laboratory level. Such variation may be a result of greater mixing of mineral signatures at the field and remote sensing levels, preferential selection of the most highly altered or mineralized rocks in field collection, signal-to-noise and reflectance calibration differences for the various measurements, and (or) differences in spectrometer sampling interval and bandpass across all levels.

\section{FUTURE WORK}

Further refinement of the MICA algorithm will be made in conjunction with $\mathrm{x}$-ray diffraction data collected from rock and soil samples in order to increase the accuracy and consistency of mineral information derived from the three scales of imaging spectrometer data. Additional analyses of the spectral data and geochemistry of hand samples will be used to better constrain the host rock mineralogy and the alteration mineral assemblages in the Orange Hill deposit.
This will help refine our interpretation of the airborne hyperspectral data and aid in identifying the central versus more distal parts of the Alaska Range porphyry systems. Cross-validation of mineral classifications from ASTER data using the HyMap2 imaging spectrometer data is ongoing to allow extrapolation of mineral information to larger areas.

\section{REFERENCES}

[1] Kokaly, R.F., King, T.V.V., and Hoefen, T.M., "Surface mineral maps of Afghanistan derived from HyMap imaging spectrometer data version 2," U.S. Geological Survey Data Series 787, 29 p., http://pubs.usgs.gov/ds/787/, 2013.

[2] Bedell, R., Crosta, A.P., and Grunsky, E., (Editors), "Remote sensing and spectral geology," Reviews in Economic Geology, v. 16, 266 p., 2009.

[3] Kääb, A., "Remote sensing of permafrost-related problems and hazards," Permafrost and Periglac. Process., v. 19, no. 2, pp. 107 136, 2008.

[4] Cocks, T., Jenssen, R., Stewart, A., Wilson, I., and Shields, T., "The HyMap airborne hyperspectral sensor-The system, calibration and performance," in Schaepman, M., Schlapfer, D., and Itten, K.I., eds., Proceedings of the 1st EARSeL Workshop on Imaging Spectroscopy, 6-8 October 1998, Zurich: Paris, EARSeL, pp. 37-43, 1998.

[5] Lenhard, K., Baumgartner, A., and Schwarzmaier, T., "Independent Laboratory Characterization of NEO HySpex Imaging Spectrometers VNIR-1600 and SWIR-320m-e," IEEE Trans. Geosci. Remote Sensing, v. 53, no. 4, pp. 1828-1841, 2015.

[6] Buchhorn, M., Kokaly, R.F., Prakash, A., Werdon, M, Cristóbal, J., and Graham, P., Field-based and airborne hyperspectral imaging for mineral exploration in the State of Alaska, Alaska Miners Association Fall Convention, Nov. 1-7, Anchorage, Alaska, 2015.

http://hyperspectral.alaska.edu/pdf/buchhorn_hylab_ama_2015.pdf [7] Kokaly, R.F., "PRISM-Processing routines in IDL for spectroscopic measurements (installation manual and user's guide, version 1.0)," U.S. Geological Survey Open-File Report 20111155, 432 p., http://pubs.usgs.gov/of/2011/1155/, 2011.

[8] Richter, D.H., "Reconnaissance geologic map of the Nabesna A-3 Quadrangle, Alaska," U.S. Geological Survey Open File Report: Technical Data Unit classification number 407, 1 sheet, scale 1:63,360, 1970.

[9] Richter, D.H., "Reconnaissance geologic map of the Nabesna A-4 Quadrangle, Alaska," U.S. Geological Survey Open-File Report 72-313, 1 sheet, 1972.

[10] Richter, D.H., "Reconnaissance geologic map of the Nabesna A-4 Quadrangle, Alaska," U.S. Geological Survey Miscellaneous Investigations Series Map 789, 1 sheet, scale 1:63,360, 1973.

[11] Richter, D.H., and Jones, D.L., "Reconnaissance geologic map of the Nabesna A-2 Quadrangle, Alaska," U.S. Geological Survey Miscellaneous Geologic Investigations Map 749, 1 sheet, scale 1:63,360, 1973.

[12] Wilson, F.H., Labay, K.A., Shew, N.B., Preller, C.C., Mohadjer, Solmaz, and Richter, D.H., "Preliminary integrated geologic map databases for the United States: digital data for the geology of Wrangell-Saint Elias National Park and Preserve, Alaska," U.S. Geological Survey Open-File Report 2005-1342, 2005. 

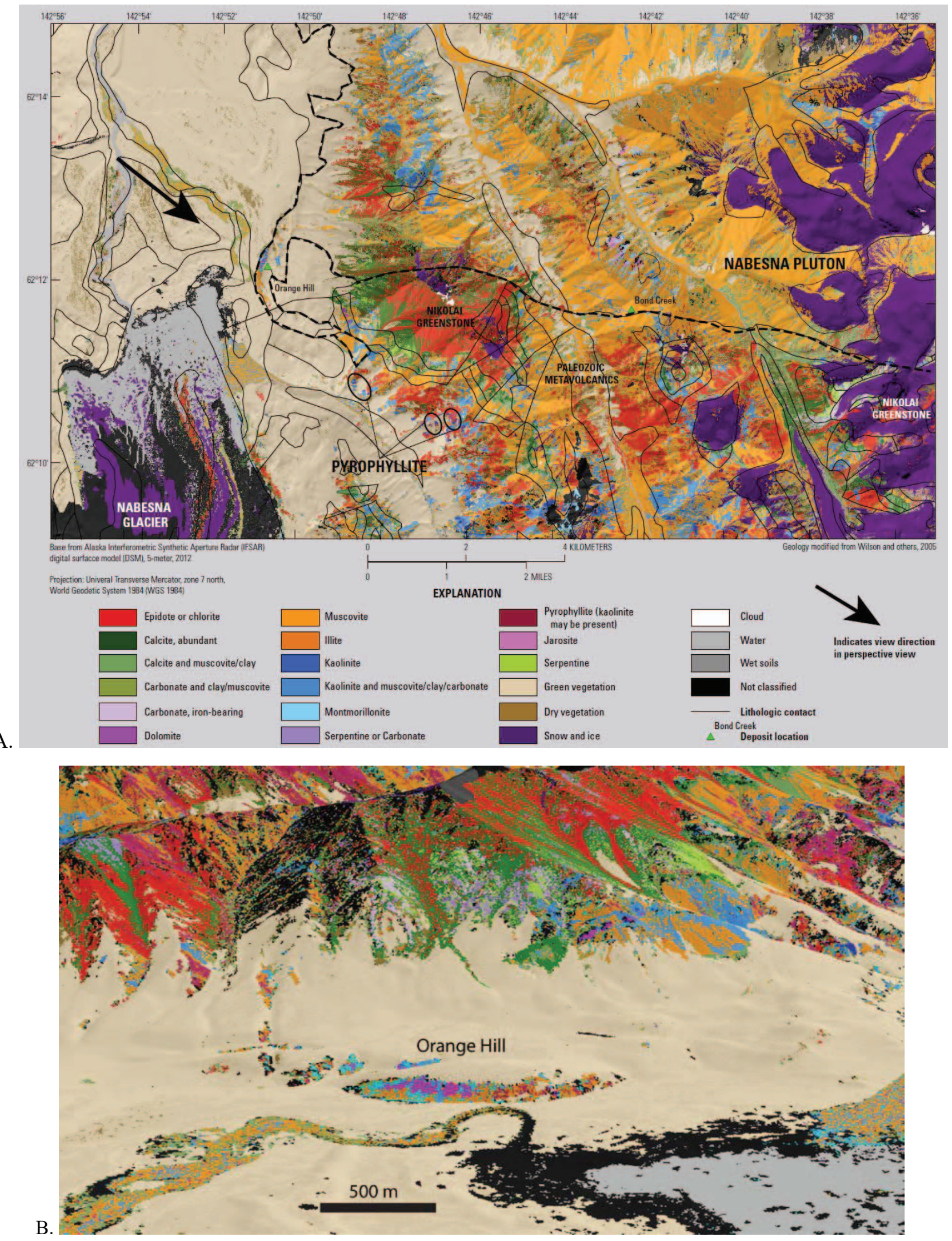

Figure 1. Preliminary mineral maps for a portion of the Nabesna AOI, near Orange Hill and Bond Creek deposits, geology from [12]. A. Mineral map draped on shaded relief in plan view. B. Mineral map draped over topography (view direction is indicated by arrow in A). 

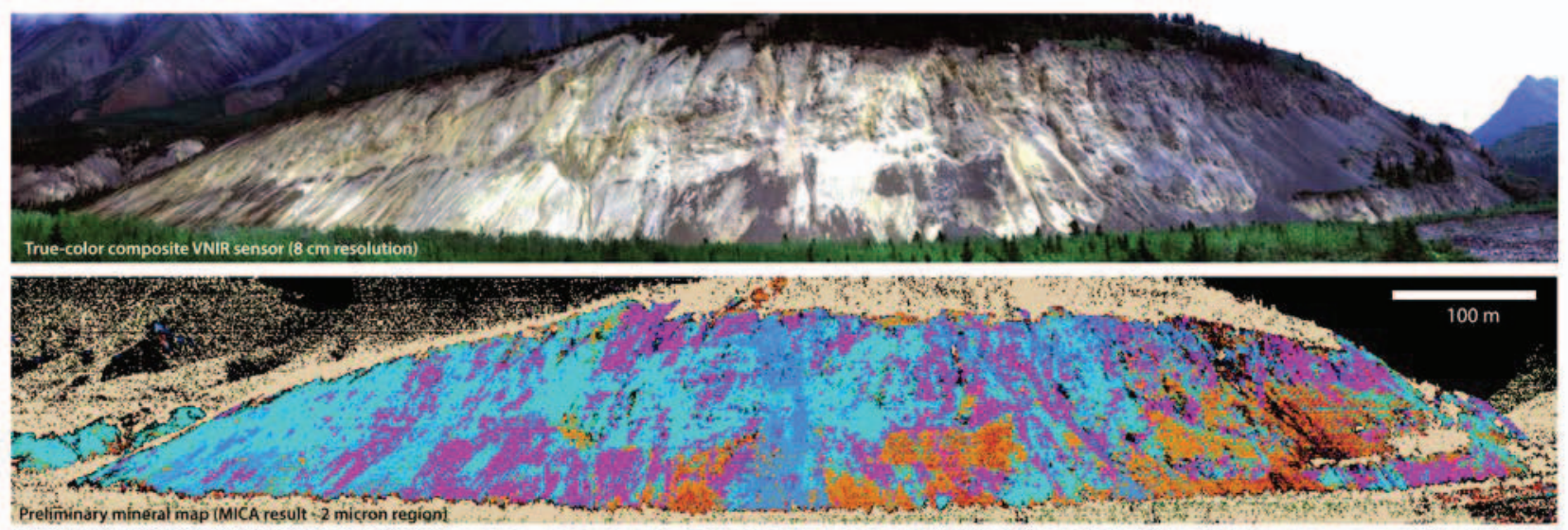
Preliminariry mineral map iMiĆ result -2 micron regio Montmorillonite $\square$ Kaolinite+Muscovite $\square$ Muscovite/litite $\square$ Chlorite+Muscovite $\square$ Chlorite $\square$ Gypsum $\square$ vegetation $\square$ Not classified

Figure 2. Preliminary mineral map from Hyspex field-based spectrometer for the western-most exposure of the Orange Hill Deposit.

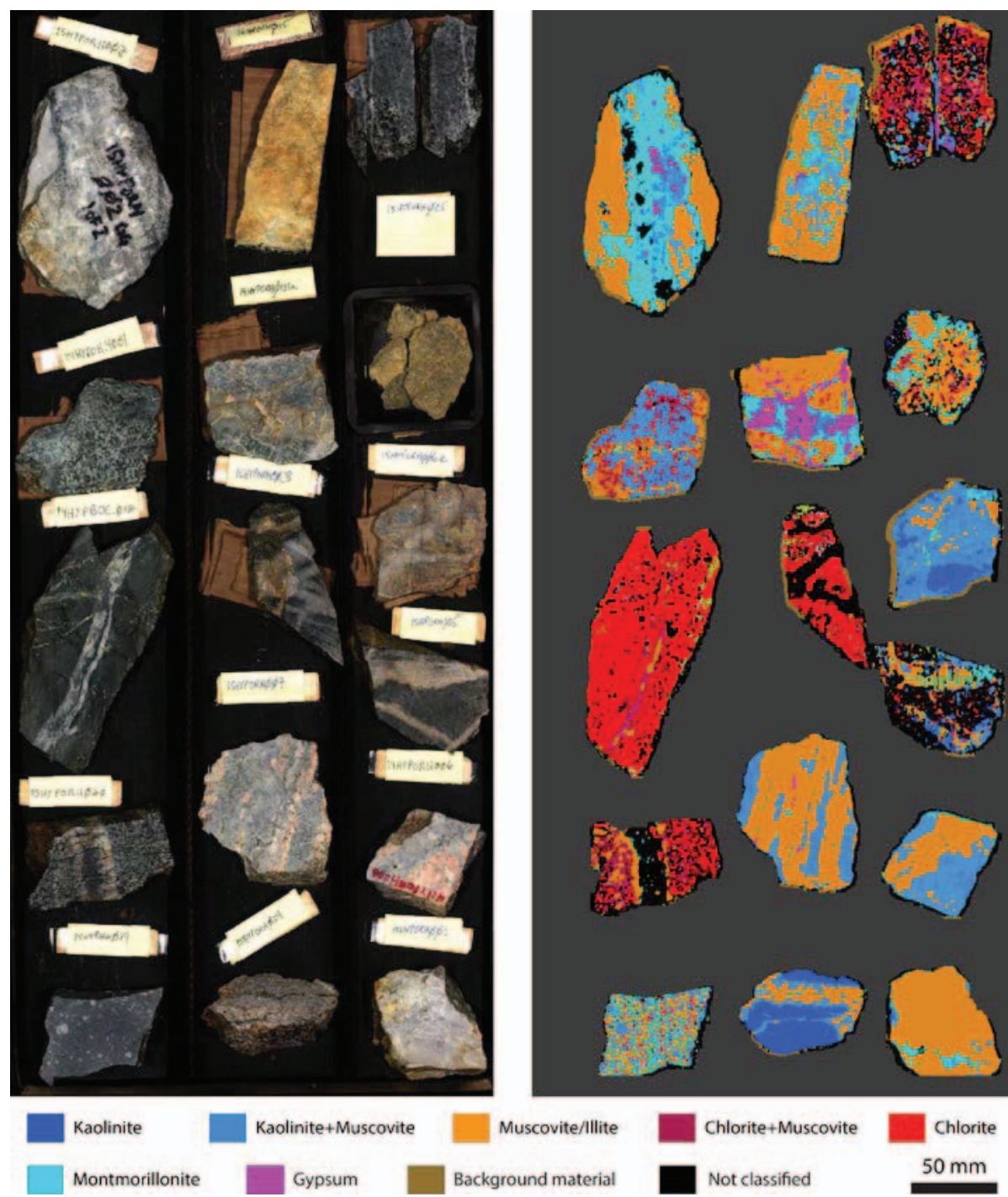

Figure 3. Preliminary mineral maps from Corescan data for hand samples collected at the Orange Hill deposit. 